\title{
A fizikai inaktivitás nemzetgazdasági terhei
}

\section{The economic burden of physical inactivity at national level}

\author{
Szerzők: $\quad$ Gabnai Zoltán ${ }^{a} \bowtie$, Müller Anetta ${ }^{b}$, Bács Zoltánc, Bácsné Bába Évab \\ a: Debreceni Egyetem, Gazdaságtudományi Kar, Gazdálkodástudományi Intézet, \\ b: Debreceni Egyetem, Gazdaságtudományi Kar, Vidékfejlesztés, Turizmus- és \\ Sportmenedzsment Intézet, c: Debreceni Egyetem, Gazdaságtudományi Kar, \\ Számviteli és Pénzügyi Intézet
}

Beküldve: 2018.05.11.

doi: $\quad$ 10.24365/ef.v60i1.308

\begin{abstract}
Összefoglaló: A fizikailag inaktív életmóddal összefüggő megbetegedések megjelenésének és növekvő prevalenciájának egyik oka, hogy az ember napjainkra valamennyi technikai vívmányát az irányba fejlesztette, hogy élete könnyebb és kényelmesebb legyen, ami társadalmi szintű fizikai inaktivitást eredményezett. A fizikai inaktivitás számos betegség kialakulásáért felel, azaz a fizikailag inaktív életmóddal megnő bizonyos betegségek kialakulásának kockázata, mint például a szív- és érrendszeri megbetegedések, a stroke, a 2-es típusú cukorbetegség, a csontritkulás, az elhízás, a magas vérnyomás vagy a stressz eredetű megbetegedések. A WHO becslései szerint a fizikai inaktivitás évente 3,3 millió halálesetért tehető felelőssé, vagyis a világon a negyedik vezető kockázati tényező. Ezen betegségek gyógyítása meghatározó arányát teszi ki az egészségügyi kiadásoknak. A fizikai inaktivitás emellett hozzájárul a produktivitás csökkenéséhez is. E két tényező nemzetgazdasági szinten óriási terhet ró a különböző országokra, így hazánkra is. Cikkünkben bemutatjuk a különböző országokban végzett, fizikai inaktivitással kapcsolatos kutatásokban számszerúsített betegségterhek adatait, elsősorban a szív- és érrendszeri betegségekre fókuszálva. Kitérünk azon kutatásokra is, melyek arra hívják fel a figyelmet, hogy az ülő életmódot (hosszú időn keresztül tartó tartós ülés, illetve pihenés) a fizikai aktivitás sem tudja teljes mértékben kompenzálni, így a hosszú ideig elhúzódó ülés jelentős kockázati tényezője a különböző kardiovaszkuláris betegségeknek. Kiemelten fontosnak tartjuk, hogy olyan interdiszciplináris együttműködéseket valósítsunk meg, amely során több terület szakembereinek (közgazdaság-, orvos- és sporttudományok) közös munkájának eredményeként az egészséggazdasági költségek modellezhetővé válnak különböző változók mentén.

Kulcsszavak: fizikai inaktivitás; ülő életmód; egészségügyi kiadások; betegségek költségei
\end{abstract}

Summary: The reason for the appearance and increasing prevalence of inactivity-related diseases is that people have developed all of the technical achievements in order to make life easier and more comfortable, which resulted in physical inactivity at a social level. Physical inactivity can be a risk factor of many diseases, such as cardiovascular diseases, stroke, type 2 diabetes, osteoporosis, obesity, hypertension or stress-related diseases. According to WHO estimates, physical inactivity accounts for 3.3 million deaths, making it the fourth leading cause of death in the world. The treatment of these diseases represents a significant proportion of health expenditures, which imposes a huge burden on the countries, including Hungary. In our article, we introduce the data regarding the costs of physical inactivity-related diseases in different countries, 
particularly focusing on cardiovascular diseases. We also point out that physical activity can not completely compensate the sedentary lifestyle (long-lasting sitting or rest) either, so long-lasting sitting can be a significant risk factor of various cardiovascular diseases.

During our research activity, we consider the implementation of interdisciplinary collaborations extremely important, which can lead to modelling healthcare costs along various variables as a result of the collaboration of specialists from several areas (economics, medicine and sports sciences).

Keywords: physical inactivity; sedentary lifestyle; healthcare expenditures; cost of illness

\section{BEVEZETÉS, TÉMAFELVETÉS}

A harmadik évezred elején a technológiai fejlődés és az életszínvonal emelkedése révén számos olyan modernkori vívmány áll az emberiség rendelkezésére, amely mindennapjainkat könnyebbé, kényelmesebbé teszi a közlekedés, a munkavégzés és a szórakozás, pihenés területén. Ennek egyik egyenes következménye a mozgásszegény életmód, vagyis a fizikai inaktivitás népességszintű elterjedése. A fizikailag inaktív életmód fogalmát többek között az Egészségügyi Világszervezet (World Health Organization, WHO) is definiálja. Általánosságban véve elmondhatjuk, hogy az egyén fizikailag inaktív életmódot folytat, ha nem végez rendszeres testmozgást, nem sportol, vagy a munkavégzése és szabadidő-eltöltése nem jár együtt rendszeres fizikai aktivitással.

$\mathrm{Az}$ Eurobarometer 2018-as kiadványa (mely 2017-es adatokat közöl és elemez) szerint a magyar lakosság esetében a rendszeresen sportolók aránya
9\%, amely a 2013-as adatokhoz képest 6\%-os csökkenést mutat. A valamilyen rendszerességgel sportolók aránya $24 \%$, ami viszont $1 \%$-os növekedés a 2013-as adatokhoz képest. A magyar lakosság körében az európai uniós átlaghoz (46\%) viszonyítva igen magas a nem sportolók aránya (53\%), mely a korábbi felmérésben publikált aránynál 9\%-kal magasabb. ${ }^{1}$

Igen széles irodalmi háttere van azon orvosi kutatásoknak, melyek igazolják a rendszeres fizikai aktivitás védőhatását a betegségek kialakulásával szemben; vagy a másik oldalról megközelítve, a fizikai inaktivitást, mint kockázati tényezőt jelölik meg a betegségek kialakulásának (vagy akár a halálozások) egyik fő okaként. 2,3,4,5,6,7,8 Többek között a lakosság életmódja, így a fizikai inaktivitás mértéke, a kapcsolódó megbetegedések szorosan összefüggnek a várható átlagos élettartam alakulásával is, amely Magyarország esetében jelentősen közel 5 életévvel - az Európai Unió (EU) átlaga alatt van. [1. ábra]

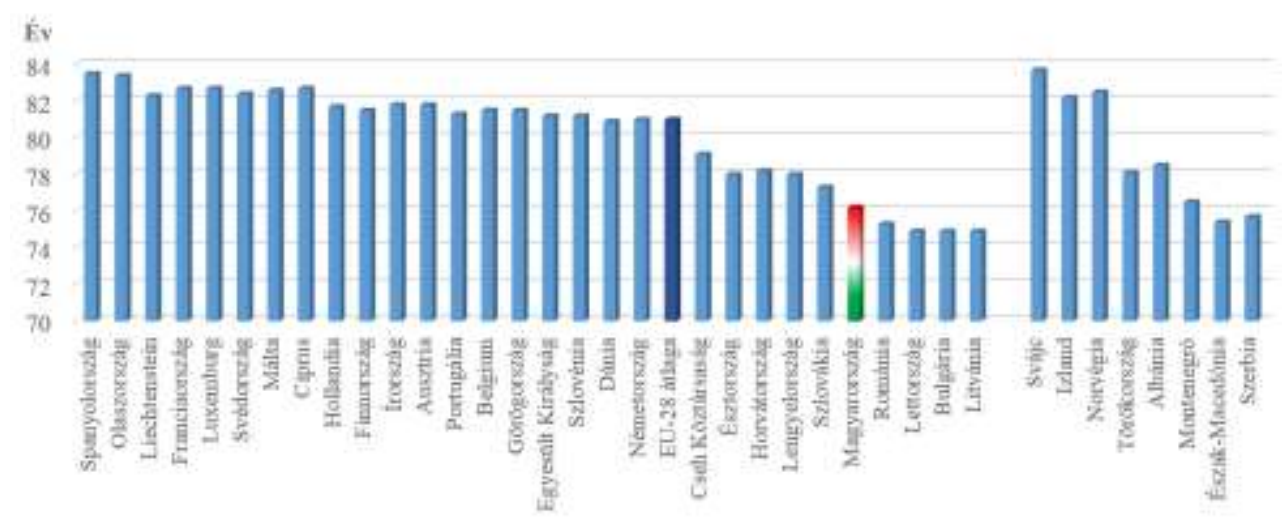

Forrás: Saját szerkesztés az Eurostat (2018) adatai alapján ${ }^{9}$ 
A fizikai inaktivitás számos betegség kialakulásáért felel, azaz a fizikailag inaktív életmóddal megnő bizonyos betegségek kialakulásának kockázata. Ezek között említhetők meg például a szív- és érrendszeri megbetegedések, a stroke, a 2-es típusú cukorbetegség, a csontritkulás, az elhízás, a magas vérnyomás, vagy éppen a stressz eredetű betegségek. ${ }^{10}$ A WHO becslései alapján a fizikai inaktivitás 3,3 millió halálesetért felel évente, amely alapján a világon a negyedik vezető kockázati tényező. ${ }^{11}$ Az Európai Unió Statisztikai Hivatalának (Statistical Office of the European Countries, Eurostat) adatai alapján a vezető halálozási okok az EU-ban a kardiovaszkuláris, valamint a daganatos megbetegedések. ${ }^{12}$ [2. ábra]

2. ábra: A föbb halálozási okok az Európai Unió országaiban (2015)

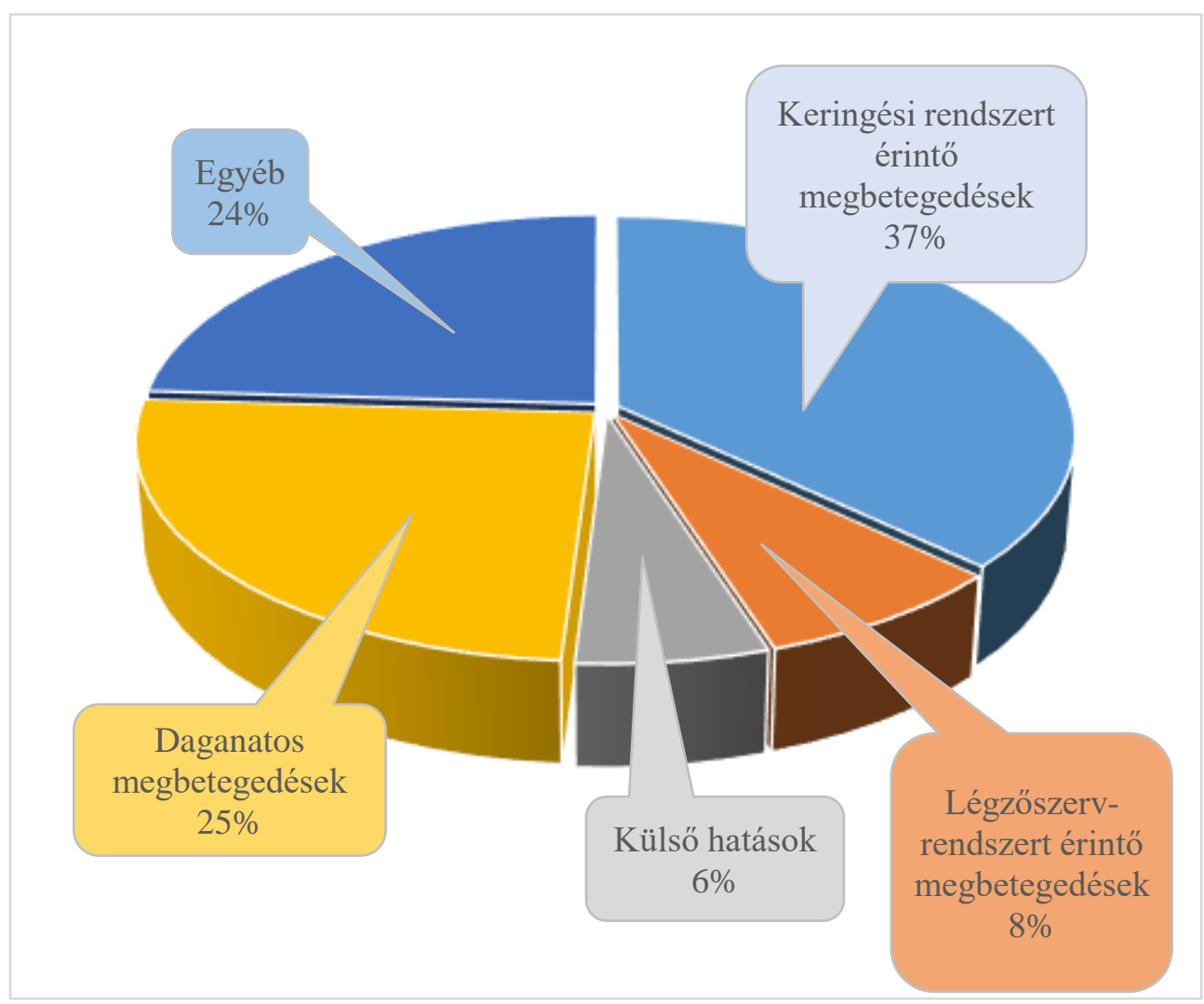

Forrás: Saját szerkesztés az EU és az OECD által kiadott Health at a Glance (2018) kiadvány adatai alapján ${ }^{12}$

Elmondható, hogy az előzőekben felsorolt - a fizikai aktivitás szintjével is összefüggésbe hozható megbetegedések megelőzésének, illetve gyógyításának gazdasági szempontból is igen komoly jelentősége van, ugyanis a hozzájuk kapcsolódó egészségügyi kiadások meghatározó arányt képviselnek az összes egészségügyi kiadáson belül. Ding és mtsai szerint dollármilliárdokban mérhető a fizikai inaktivitás miatt a társadalmakra rótt gazdasági teher. A fizikai inaktivitás és az ülő életmód, a magas kalóriabevitel eredményeként az elhízás és a túlsúly korunk egyik népbetegsége lett. ${ }^{13}$
A fejlett országokban az utóbbi évtizedekben jelentősen felértékelődött az egyén szerepe, felelőssége az egészségmegőrzés és az egészséges életmód kialakítása terén. Ezzel párhuzamosan a hagyományos gyógyszerek mellett megjelentek a különféle gyógyhatású termékek, nő a preventív célt szolgáló, ún. nem vényköteles készítmények választéka ${ }^{14,15}$, és a funkcionális élelmiszerek választékával egyben a kereslet is növekedett. ${ }^{16}$ Ezek mellett a különböző vitaminokat, nyomelemeket és ásványi anyagokat tartalmazó, illetve probiotikus készítmények száma és kereslete is növekedett az utóbbi időben. 
A statisztikák szerint az egyének egyre többször fordulnak az öngyógyításhoz, azaz vény nélkül beszerezhető gyógyszerekkel kívánják orvosolni kisebb-nagyobb egészségügyi problémáikat. ${ }^{17,18}$ Az egészségügyet érintő trendek között hazánkban is megfigyelhető, hogy megjelent az alternatív és komplementer medicina iránti igény, melyet egyre több fogyasztó vesz igénybe és részesít előnyben a klasszikus, nyugati orvoslással szemben. Az alternatív gyógymódok iránti megnövekedett érdeklődést igazolja a hazai és nemzetközi kutatások növekvő száma. ${ }^{19,20,21,22,23} \mathrm{Az}$ egészségtudatosság jegyében minden olyan preventív célt szolgáló termék vagy szolgáltatás fogyasztása növekszik, melyet az egészségtudatos vásárlók a betegségek megelőzésére alkalmaznak, legyen az sportszolgáltatás vagy élelmiszeripari termék, gyógyhatású készítmény.

A fizikai inaktivitás és annak következményei nemzetgazdasági szinten óriási terhet rónak az egyes országokra, így hazánkra is. Ács és mtsai cikkében látható, hogy a fizikai inaktivitással is összefüggésbe hozható megbetegedések (szív- és érrendszeri betegségek, vastagbélrák, 2-es típusú diabétesz, csontritkulás) tekintetében az Országos Egészségbiztosítási Pénztár (OEP) kiadásainak teljes értéke 2009-ben meghaladta a 200 Mrd Ft-ot. ${ }^{24}$

Elmondható, hogy a fizikai inaktivitással összefüggő gazdasági terhek becslése és számszerűsítése napjainkban egyre inkább előtérbe kerülő témakör. Az ennek céljából megvalósult kutatások, tanulmányok azonban módszertanilag gyakran eltérnek egymástól, amely sok esetben megkérdőjelezhető eredményekre és következtetésekre vezet. ${ }^{25}$

A hazai és a nemzetközi irodalom áttekintése során azokra a tanulmányokra fókuszáltunk, amelyek a fizikai inaktivitással kapcsolatos egészségügyi terheket, valamint azok számítási módszereit mutatják be. Cikkünkben elemezzük a fizikai inaktivitással összefüggő költségek számszerűsítésére is alkalmazható populációs járulékos kockázati mutatót (Population Attributable Risk, azaz PAR, amely a megbetegedések azon aránya, amely valószínúsíthetően az adott rizikófaktor miatt következik be), továbbá említést teszünk alkalmazásának korlátairól is.
Mivel a szívkoszorúér-betegségek esetében a fizikai aktivitás kimutathatóan és igazolhatóan csökkenti azok előfordulását, így az egyik legköltséghatékonyabb és talán a legfontosabb megelőzési mód a lakosság fizikai aktivitásának növelése, amely az egészségügyi kiadások csökkentéséhez vezet.

\section{MÓDSZEREK}

Tanulmányunk összeállításakor a fizikai inaktivitással járó betegségek nemzetgazdasági terheinek bemutatására, valamint azok mérésére fókuszáló releváns külföldi és hazai kutatásokra támaszkodtunk. Munkánk során a kutatások kiválasztása oly módon történt, hogy megjelenjenek a fizikai aktivitás, a kardiovaszkuláris (szívkoszorúér) betegségek, a betegségekkel kapcsolatos költségek és a fizikai inaktivitás gazdasági terheire utaló címszavak, illetve tartalmak. Cikkünkben elsősorban a hazánkat is igen érzékenyen érintő, magas prevalenciával járó szívkoszorúér-betegségek költségvonzatával kapcsolatos publikációk bemutatására fókuszáltunk, röviden kitérve a témakörhöz kapcsolódó egyéb területekre. A Web of Science, Scopus és Google Scholar adatbázisokban az egészség, fizikai aktivitás, magyarok tápláltsági állapota, cost of illness kifejezésekre kerestünk rá 1990-től 2018-ig, majd ezekből válogattunk. Az így kapott találatok közül azokat preferáltuk, melyek szövege elektronikus formában rendelkezésünkre állt. Emellett olyan forrásokat is felhasználtunk, melyeket korábbi kutatómunkánk során tekintettünk át és jelen cikk szempontjából relevánsnak ítéltünk. Az eredeti tanulmányok mellett az áttekintő közleményeket is felhasználtuk.

\section{EREDMÉNYEK}

A megbetegedésekkel kapcsolatos költségek alakulására és vizsgálatára számos módszertani lehetőség kínálkozik. Ezek közül legismertebbek a COI- (Cost of Illness, betegségek költségei), a WTP(Willingness to Pay, fizetési hajlandóság), a DALY(Disability Adjusted Life Years, egészségkárosodással korrigált életévek), valamint a QALY- (Quality Adjusted Life Years, életminőséggel korrigált 
életévek) módszerek. A COI és a WTP a pénzben kifejezhető költségeket, míg a DALY és a QALY a nem, vagy csak nehezen számszerüsíthető terhek, az egészségi állapotban bekövetkező változások kifejezésére alkalmazhatóak. A betegségterhekkel foglalkozó módszertanok egyik fontos csoportját képezik a COI-vizsgálatok, amelyeket a betegségekkel kapcsolatos költségek számszerűsítése céljából az Amerikai Egyesült Államokban már az 1970-es évektől kezdve alkalmaznak az egészségügyi döntés-előkészítésének megalapozására. Bloom és mtsai szerint a tanulmányok legfontosabb funkciója a hatékony döntés-előkészítésben keresendő, legfőbb céljai ugyanakkor a következők: (1) a pillanatnyi helyzet meghatározása; (2) a technológiai innovációnak vagy erőforrás-felhasználás fejlődéséből következő időbeli változások mérése; (3) új kutatási hipotézisek megalkotása. ${ }^{26}$ Clabaugh és mtsai a COI-vizsgálatok fontosságát abban látják, hogy a betegségekhez kapcsolódó költségek számszerúsítése, meghatározása által kiváló lehetőség adódik mind a lakossággal, mind a döntéshozókkal való kommunikációra. ${ }^{27}$ A módszer fejlődésével ezen elemzések igen fontossá váltak a különböző betegségek költséghatékony kezelésével és megelőzésével kapcsolatos kutatási-fejlesztési tevékenységek, valamint egészségpolitikai kezdeményezések megalapozásaként.

A releváns szakirodalomban számos kutatási eredményt ismerhetünk meg a különböző országokra vonatkozóan, melyek célja a lakosság fizikai aktivitásának növelésével történő egészségügyi költségmegtakarítás és gazdasági produktivitás számszerúsítése, illetve prognosztizálása.

Janssen a szabadidősport, a rendszeres testedzés gazdasági hatásrendszerét vizsgálva, a kanadai felnőttekre vonatkozóan a fizikai inaktivitás direkt, indirekt és összes költségét kalkulálva a következő értékeket jelölte meg: (1) direkt: 2,4 Mrd USD, (2) indirekt: 4,3 Mrd USD és (3) összes: 6,7 Mrd USD, amely mai értékre átszámítva összesen 2,2 billió Ftot jelent. ${ }^{28}$ Allender és mtsai 1,06 Mrd GBP-re becslik az Egyesült Királyságban a fizikai inaktivitás nemzeti költségét, ami mintegy 624 Mrd Ft-nak felelne meg a cikk megjelenésekor. ${ }^{29}$

Általánosságban elmondható, hogy a magasabb mértékú fizikai aktivitás - a gazdaságot makroökonómiai szempontból vizsgálva - emeli a bruttó hazai terméket, a termelékenységet, csökkenti a munkanélküliséget. A vállalkozások számára pedig összességében kevesebb munkahelyi hiányzást, betegséget, táppénzt és munkahelyi balesetet eredményez. Vagyis azon személyek, akik fizikailag aktívak, több testmozgást végeznek, jobb kondicionális és koordinációs képességgel bírnak, így a motoros képességek magasabb szintje miatt stabilabb munka- és feladat-végrehajtás is jellemzi őket.

Fizikai aktivitás hatása a kardiovaszkuláris betegségek prevenciójában

Különböző vizsgálatokban a fizikai aktivitás védőhatásáról számoltak be, mely csökkentette a szívés érrendszeri betegségekből eredő halálozások számát a vizsgált populációban. ${ }^{30,31,32,33,34}$

Franco és mtsai a különböző intenzitású fizikai aktivitás szerepét vizsgálták a kardiovaszkuláris betegségek prevenciójában az 50 év feletti populációban. ${ }^{35} \mathrm{~A}$ fizikai aktivitás 3 szintjét (alacsony, közepes és intenzív) különböztették meg, valamint a dohányzás mértékét és a társbetegségek előfordulását is vizsgálták. Megállapították, hogy a közepes és a magas intenzitású fizikai aktivitást végző férfiak 1,3-3,7, illetve 1,1-3,2 évvel élnek tovább szívkoszorúér-betegségek nélkül, mint azon társaik, akiknek a fizikai aktivitási szintje alacsony. A nők esetében a fizikailag aktívabbak egészséges életéveinek száma 1,5-3,5 évvel több, és 1,3-3,3 évvel élnek tovább szívkoszorúér-betegségek nélkül, mint akik fizikai aktivitása alacsonyabb mértékű. A fizikailag aktív felnőttek esetében a szívkoszorúér-megbetegedés mortalitásnak körülbelül feleakkora a kockázata a fizikailag inaktívakhoz képest. Már a mérsékelt intenzitású fizikai aktivitás is bizonyítottan egészségügyi előnyökkel jár. A fizikai aktivitás a megbetegedések és a halálozás kockázatának csökkentésére szolgál az isémiás szívbetegségek tekintetében, ha a fizikailag inaktív személyekhez hasonlítjuk az adatokat, vagyis az egészségügyi előnyt. ${ }^{36}$

Chomistek és mtsainak tanulmánya bebizonyította, hogy az elhúzódó ülőidő a szabadidős fizikai aktivitástól függetlenül a szív- és érrendszeri betegségek kockázatával jár együtt. ${ }^{37}$ Ugyanakkor egy másik, 
utánkövetéses vizsgálat megállapította, hogy azoknál az ülő életmódot folytató nőknél, akik fizikailag aktívak voltak a felmérés kezdetén, valamint 6 évvel később is, azoknál 32\%-kal alacsonyabb volt a szívkoszorúér-betegségek előfordulása és 38\%-kal alacsonyabb volt a szívkoszorúér-betegségek miatti mortalitás, szemben azokkal a nőkkel, akik a felmérés mindkét időpontjában ülő életmódot folytattak..$^{38}$

\section{A populációs járulékos kockázat mutató alkalmazási lehetőségei}

A nemzetközi szakirodalomban gyakran találkozhatunk a PAR-mutató alkalmazásával, mely segítséget nyújthat az egészségköltségek (és különösen a fizikai inaktivitás költségeinek) becslésére is.

A PAR-mutató hasonló esetekben alkalmazható képlete - Powell alapján ${ }^{39}$ - a következő:

$$
P A R=\frac{P_{\exp } \times(R R-1)}{1+P_{\exp } \times(R R-1)} \times 100
$$

ahol:

$P_{\text {exp }}$ : a lakosság azon része, amely ki van téve egy adott kockázati tényezőnek („exposed”)

RR (Relative Risk, vagyis relatív kockázat): kifejezi, hogy hányszor nagyobb a kockázati tényezőnek kitett populáció megbetegedési kockázata (jelen esetben a fizikailag inaktív életmódnak köszönhetően).

A PAR-mutató tehát egy adott koncepción alapuló mutatószám, amely egészségügyi eredmények számszerúsítésére alkalmazható egy olyan képzeletbeli világban, ahol az emberek csupán a fizikai aktivitásukat változtatják meg, és semmi mást. A mutató korlátja, hogy nem tér ki a személy más viselkedési kockázatára vagy más életmódelemre. Emellett nem veszi figyelembe és nem vizsgálja a fizikai állapotot, illetve annak változását - például a vérnyomást vagy a vér koleszterinszintjét (azaz feltételezi, hogy ezek az adatok konstansak). ${ }^{40}$ A legtöbb krónikus betegség ugyanakkor társbetegségekkel jár együtt, melyeknek több kiváltó oka lehet. Amennyiben a vizsgált személynél egyszerre több kockázati tényező is fennáll (pl. dohányzás, fizikai inaktivitás, magas vérnyomás, magas szérumkoleszterin a szívkoszorúér-betegséggel összefüggésben), akkor ezekre egyenként külön PAR-becslések számíthatók ki, azonban ezek a becslések nem adhatók össze. Ahogy V. Hajdú és Ádány megfogalmazzák: „az elméletileg nagy jelentőségú és igen egyszerúen számítható járulékos kockázati mutatók alkalmazása a gyakorlatban, konkrét esetekben nagy óvatosságot igényel. Számításuk során ugyanis elfogadjuk azt a feltételezést, hogy a tanulmányozott megbetegedés elófordulását - a vizsgált kockázati tényezőn kívül befolyásoló egyéb tényezők azonos mértékben vannak jelen az exponált és a nem exponált csoportban egyaránt. Ez a gyakorlatban csak ritkán, kivételes esetekben teljesül, ezért a járulékos kockázati mutatók értékét súlyos torzítások, zavaró hatások terhelhetik" ${ }^{41}$

Hazai mintára vonatkozóan alkalmazták a PARmutatót Ács és mtsai, a következő eredménnyel: „Amennyiben 77\%-ról 67\%-ra csökkenne a fizikai inaktivitás a magyar népesség körében, az 4,3-6,3 Mrd Ft-ig terjedő intervallumon belüli megtakarítási összeget eredményezne az OEP kiadásai között". ${ }^{24}$ A relatív kockázati ráta megállapításához felhasználták a Katzmarzyk és mtsai által készített metaanalízisben meghatározott összesített relatív kockázati arányt. ${ }^{42}$ Érdekes kérdés, hogy hazánkban ez az RR-érték relevánsnak tekinthető-e, mivel nem tartalmaz hazai kutatási eredményt az RR vonatkozásában, továbbá alkalmazható-e a magyar populációra nézve.

A fizikai aktivitás-inaktivitás megállapítása az Ács és mtsai által publikált cikkben az Eurobarometer 2009-es felmérésén alapult, ahol a szerzők a lakosság fizikailag inaktív részének azokat tekintették, akik egyáltalán nem vagy csak néha sportolnak, azaz a fizikai aktivitásuk mértékében nem figyelhető meg rendszeresség.

Berlin és Colditz 9 tanulmány metaanalíziséből adaptálták az RR 1,9-es (1,6-2,2 konfidencia-intervallummal) értékét. A 90-es évek utáni számos egészséggazdasági vonatkozású publikáció pedig arról számol be, hogy a kardiovaszkuláris betegségek esetében a fizikai inaktivitás RR értéke 2-10 között van. ${ }^{27,43}$ 
Összefoglalva, a PAR-mutató hasznos eszköz lehet a fizikai inaktivitás népegészségügyi terheinek a megértésére és annak a számszerüsitésére, mely figyelembe veszi a fizikai aktivitások különböző terhelési szintjét. Ugyanakkor a becslések helyességének alátámasztása érdekében mindenképpen szükségesnek tartjuk a módszertan továbbfejlesztését a korábban megfogalmazott hiányosságok és esetlegesen adódó pontatlanságok elkerülésének érdekében.

\section{A mutató korlátaira rávilágító kutatások tapasztalataiból}

A PAR-mutató alkalmazásának további korlátja, hogy vizsgált populáción belül csak a fizikailag aktív személyekkel számol, ugyanakkor egyes kutatások $^{44,45,46}$ felhívják a figyelmet arra is, hogy a fizikai aktivitás intenzitása sem elhanyagolható az egészségügyi előnyök megállapításakor, valamint az a tény sem hagyható figyelmen kívül, hogy a fizikailag aktív személyek vajon életük végéig azok maradnak-e ${ }^{47}$ - a mutató ugyanis ezt feltételezi.

Több kutatás rávilágít tehát arra, hogy a fizikai aktivitás vagy sportolás mérésekor nem hagyható figyelmen kívül a testmozgás intenzitása. Paffenbarger és mtsai tanulmányukban bizonyítékot szolgáltattak az edzéssel és egészséggel összefüggő lényeges fogalmakkal kapcsolatban. ${ }^{44}$ Először is megállapítottak egy olyan gyakorlati küszöbértéket a testmozgás vagy edzés intenzitását illetően, aminek teljesülése esetén az egészségügyi előnyök megvalósulnak. Ennek számszerűsítéséhez ad segítséget a metabolikus egység (Metabolic Equivalent, azaz MET) alkalmazása. A gyakorlati küszöbérték mértéke kb. 5-6 MET, amellyel a testmozgás mennyiségi paraméterén túl (heti 1-szer, 2-szer, vagy heti 150 perc stb.) a testmozgás intenzitására is javaslatot tesz, mely 1000-2000 kcal/hét elégetésével ekvivalens. Ez az az érték, ami a szívkoszorúérbetegségek miatti halálozást jelentős mértékben csökkenti. Fontos megállapítása a tanulmánynak, hogy az egészséghez szükséges fizikai aktivitásnak legalább közepes intenzitásúnak kell lennie, valamint megfigyelték a túlzott terheléssel járó kockázatot is.

Végül a sportolással és testmozgással (lépcsőzés, gyaloglás) kapcsolatos egészségügyi előnyök akkor érvényesültek, ha a fizikai aktivitás egész életen át tartott. Azaz a sportolás jótékony hatása akkor járult hozzá az egészséghez, ha az tartós fogyasztási cikként épült be az egyén életébe. Így a PAR-számítások újabb kritikájaként lehet megemlíteni azt, hogy az adatfelvétel időpontjában fizikailag aktív, vagy inaktív személyekről feltételezzük, hogy ez az állapot változatlan marad. Az alumni vizsgálatból kiderült, hogy azon egyének körében, akik egyetemi éveik alatt sportoltak, majd azt abbahagyták és fizikailag inaktívakká váltak, magasabb volt a szívkoszorúér-betegségek előfordulása, és az ebből eredő halálozási arány, mint azok körében, akik az egyetemi éveiket követően is sportoltak és fizikailag aktív életmódot folytattak. Ráadásul azok körében is kedvezőbb volt a halálozási arány, akik ugyan nem sportoltak egyetemi éveik alatt, viszont később a sport, a rendszeres fizikai aktivitás életmódelemükké vált. ${ }^{47}$

Arem és mtsai nagymintás vizsgálata alapján a fizikailag inaktívakhoz képest 20\%-kal csökken a mortalitás kockázata azoknál is, akik a hetente minimálisan ajánlott 7,5 MET-nél kevesebbet sportolnak, 31\%-kal kisebb az érték minimum 1-2szeresét végzők körében, és 37\%-kal alacsonyabb a kockázat a minimális érték 2-3-szorosának megfelelő sporttevékenységet végzők esetében. A felmérés alapján az ajánlott minimum érték 3-5szörösénél van a kockázatcsökkentő hatás felső határa. A tanulmány a daganatos és kardiovaszkuláris betegségek halálozási rátája esetén is hasonló eredményeket igazol, egyben megerősíti a 2008-as „Physical Activity Guidelines for Americans” az Amerikai Egyesült Államok lakosságának szóló fizikai aktivitás mértékéről szóló ajánlásában megfogalmazott heti mozgásmennyiség (minimum 75 perc erős vagy 150 perc közepes intenzitású fizikai aktivitás) egészségügyi előnyeit. ${ }^{45}$

Guthold és mtsai tanulmányukban 358 felmérés eredményeit foglalták össze a világ 168 országára

\footnotetext{
i A cikkben említett, az Amerikai Egyesült Államok lakosságának készült, fizikai aktivitás mértékéről szóló ajánlásnak (Physical Activity Guidelines for Americans) időközben megjelent a második kiadása:

U.S. Department of Health and Human Services. Physical Activity Guidelines for Americans, 2nd edition. U.S. Department of Health and Human Services, Washington, DC, 2018. https://health.gov/paguidelines/second-edition/pdf/Physical_Activity_Guidelines_2nd_edition.pdf
} 
vonatkozóan. A kutatás alapján az elégtelen szintú fizikai aktivitás világszinten 27,5\%-os mértékü (a nemek között 8\%-os eltéréssel, a férfiak javára). Az elégtelen fizikai aktivitást felnőttek esetében a következőképpen definiálták: azon személyek, akik a heti 150 perc közepes intenzitású, vagy a 75 perc magas intenzitású fizikai aktivitásnál vagy a kettő kombinációjából számított egyenértéknél kevesebbet teljesítettek. A fizikai inaktivitás leginkább Latin-Amerikában és a Karib-térségben (44\%), Dél-Ázsiában (43\%) és a magas jövedelemszintû nyugati országokban (42\%), míg a legkevésbé Óceániában (12,3\%), Kelet- és Délkelet-Ázsiában (17,6\%), valamint a szubszaharai régióban (17,9\%) volt megfigyelhető. Az elégtelen fizikai aktivitás szintje a tehetősebb országokban kétszerese volt az alacsony jövedelmi szinttel jellemezhető országokénak. ${ }^{46}$

\section{KÖVETKEZTETÉSEK ÉS JAVASLATOK}

A fizikai inaktivitás szerepét már felismerték, mint a betegségek kialakulását fokozó kockázatot, de a lakosság fizikai aktivitásának növelésére tett erőfeszítéseket egyelőre az összehangoltság hiánya és az alulfinanszírozás jellemzi. Azért, hogy az elérni kívánt célok, és a ténylegesen megvalósított beavatkozások eredményei minél jobban közelítsenek egymáshoz, nélkülözhetetlen a körültekintő és megalapozott szocio-ökonómiai elemzések megvalósítása és tanulmányok kidolgozása.

A jövőben megvalósuló vizsgálatok esetében kiemelten fontos, hogy azok interdiszciplinárisak legyenek, vagyis több terület szakemberei (a közgazdászoktól a "testmozgás” szakértőkig) dolgozzanak együtt a különböző társadalmi- gazdasági elemzéseken, felhasználva a korábban megvalósult kutatások tapasztalatait és módszertanát. Az elemzések során fontos kiemelt figyelmet fordítani az egyes zavaró és limitáló tényezőkre, fordított oksági és komorbiditási faktorokra is.

\section{ÖSSZEFOGLALÁS}

Az aktív életmód ösztönzésének valamennyi korosztály számára ${ }^{48,49,50,51}$ mind a prevencióban, mind a megbetegedések kezelésében igen jelentős szerepe lesz a jövőben, amely a társadalom testilelki állapotának javítása, 52,53,54 így a jóllét elérésének elősegítése $e^{55,56,57}$ mellett komoly gazdasági megtakarítást is eredményez ${ }^{58}$ mind a nemzetgazdaság, mind a háztartás szintjén. Kutatások igazolták, hogy a kardiovaszkuláris betegségek esetében a testmozgás alternatív terápiának felel meg, illetve azok prevenciójában is jelentős szerepet játszik. Az elhízás visszaszorításában a hazai szakirodalom is a komplex beavatkozás szükségességét emeli ki, miszerint az egészségmagatartást leginkább a tudásbővítés, a motiválás és a támogató környezet kialakításán keresztül lehet pozitív irányba mozdítani. ${ }^{59}$

\section{KÖSZÖNETNYILVÁNÍTÁS}

A publikáció elkészítését a "GINOP-2.3.2-15-201600062 Életminőség fejlesztése Kelet-Magyarországon: Táplálkozás-, teljesítménybiológiai és biotechnológiai experimentális kutatások és eszközfejlesztések a humán megbetegedések megelőzésére és kezelésére" projekt támogatta.

\section{HIVATKOZÁSOK}

\footnotetext{
${ }^{1}$ European Commission: Sport and physical activity. Special Eurobarometer 472. Report. 2017. doi: 10.2766/483047

2 Diabetes Prevention Program Research Group: Reduction in the incidence of type 2 diabetes with lifestyle intervention or metformin. N Engl J Med 2002; 346:393-403 doi: 10.1056/NEJMoa012512

${ }^{3}$ Pereira MA, Folsom AR, McGovern PG, et al. Physical activity and incident hypertension in black and white adults: the Atherosclerosis Risk in Communities Study. Prev Med. 1999;28(3):304-12. doi: 10.1006/pmed.1998.0431

${ }^{4}$ Katzmarzyk PT, Janssen I, Ardern Cl. Physical inactivity, excess adiposity and premature mortality. Obes. Rev.

2003;4:257-290. doi: 10.1046/j.1467-789X.2003.00120.x
} 
${ }^{5}$ Lee IM, Paffenbarger RS. Physical activity and stroke incidence. Stroke. 1998;29:2049-54. doi: 10.1161/01.STR.29.10.2049

${ }^{6}$ Lee CD, Folsom AR, Blair SN. Physical activity and stroke risk: a meta-analysis. Stroke. 2003;34:2475-2481.

doi: 10.1161/01.STR.0000091843.02517.9D

${ }^{7}$ Ekelund U, Griffin SJ, Waareham NJ. Physical activity and metabolic risk in individuals with family history of type

2 diabetes. Diabetes Care. 2007;30:337-342. doi: 10.2337/dc06-1883

${ }^{8}$ Apor P. Fizikai edzés a cukorbetegség megelőzésében és kezelésében. Orv. Hetil. 2009;150(13):579-587.

doi: $10.1556 / \mathrm{OH} .2009 .28550$

${ }^{9}$ Statistical Office of the European Countries. Life expectancy at birth, 1980-2016. Statistics Explained. 2018.

https://ec.europa.eu/eurostat/statistics-explained/index.php?title=Mortality and life expectancy statistics\#Life expectancy at birth increased in 2016 (Elérve: 2018. 11. 30.)

${ }^{10}$ Apor P. Testedzéssel a megbetegedések ellen. Magyar Tudomány. 2012;173:1470-1477.

http://www.matud.iif.hu/2012/12/09.htm (Elérve: 2018. 02. 12.)

${ }^{11}$ Pratt M, Norris J, Lobelo F, et al. The cost of physical inactivity: moving into the 21st century. Br J Sports Med. 2014;48:171-173. doi: 10.1136/bjsports-2012-091810

12 OECD/EU. Health at a Glance: Europe 2018: State of Health in the EU Cycle. OECD Publishing, Paris. doi: $10.1787 /$ health glance eur-2018-en

${ }^{13}$ Ding D, Lawson KD, Kolbe-Alexander TL, et al. The economic burden of physical inactivity: a global analysis of major non-communicable diseases. Lancet. 2016;388:1311-1324. doi: 10.1016/S0140-6736(16)30383-X

${ }^{14}$ Lányi B. A pult fölött ... avagy OTC. In: Bányai E, Lányi B, Törőcsik M. (szerk.): Tükröződés, társtudományok, trendek, fogyasztás. Pécsi Tudományegyetem, Közgazdaságtudományi Kar, Pécs. 2017. pp 678-687.

${ }^{15}$ Szabó Cs. Gyógyszeripari trendek - fókuszban a tételes finanszírozású gyógyszerek. Medical Tribune Konferencia. 2013. március 12. Budapest. http://www. medicalonline.hu/download.php?id=13511 (Elérve: 2018. 01. 22.)

${ }^{16}$ Szakály Z, Kiss M, Jasák H. Funkcionális élelmiszeres, fogyasztói attitűdök és személyre szabott táplálkozás.

Táplálkozásmarketing. 2014;1(1-2):3-17. doi: 10.20494/TM/1/1-2/1

17 Törőcsik M. Fogyasztói magatartási trendek hatása az egészségügyi szolgáltatókra. Egészségügyi Gazdasági Szemle. 2003. január-március, pp 28.

${ }_{18}$ Müller A, Kerényi $E$. Trendek és fogyasztói magatartás az egészségügyben. Egészségügyi marketing és telekommunikáció c. konferencia kiadványkötete. Mátrai Gyógyintézet. Magyarország, Kékestető. 2009. pp 11-19.

${ }^{19}$ Csörgő T, Bíró M, Kopkáné Plachy J, et al. Masszázsterápia hatásának vizsgálata 60 év feletti nők körében. Acta Academiae Agriensis. 2013;40:5-17. http://publikacio.uni-eszterhazy.hu/752/1/5-16 Csorgo.pdf (Elérve: 2017. 11. 16.)

${ }^{20}$ Harris PE, Cooper KL, Relton C, et al. Prevalence of complementary and alternative medicine (CAM) use by the general population: a systematic review and update. PRACTICE (ESHER). 2012;66:924-939. doi: 10.1111/j.17421241.2012.02945.x

${ }^{21}$ Müller A, Kerényi E, Könyves E. Effect of climate therapy and rehabilitation in Mátra Medical Institute. APSTRACT. 2011;5:40-42. http://ageconsearch.umn.edu/bitstream/104664/2/5 Muller Effect\%20of\%20climate Apstract.pdf (Elérve: 2017. 11. 17.)

22 Lengyel A. A Figyelem és Tudatosság Mindfulness Skála (FTMS) pilot tesztelése: egyes módszertani problémák megoldási alternatíváinak vizsgálata. Mentálhigiéné és Pszichoszomatika. 2017;18:334-64.

https://doi.org/10.1556/0406.18.2017.015

${ }^{23}$ Lengyel A. Tourism, meditation, sustainability. APSTRACT. 2016;10:81-92. http://ageconsearch.umn.edu/bitstream/244458/2/11 APSTRACT 201601 WEB JAV.pdf (Elérve: 2017. 11. 17.)

${ }^{24}$ Ács $P$, Hécz R, Paár D, et al. A fittség (m)értéke. A fizikai inaktivitás nemzetgazdasági terhei Magyarországon. Közgazdasági Szemle. 2011;58:689-708. http://unipub.lib.uni-corvinus.hu/440/1/Kszemle_CIKK_1259.pdf (Elérve: 2017. 09. 10.)

${ }^{25}$ Ding D, Kolbe-Alexander T, Nguyen B, et al. The economic burden of physical inactivity: a systematic review and critical appraisal. Br J Sports Med. 2017;51:1392-1409. doi: 10.1136/bjsports-2016-097385

${ }^{26}$ Bloom BS, Bruno DJ, Maman DY, et al. Usefulness of US cost-of-illness studies in healthcare decision making. Pharmacoeconomics. 2001;19:207-213. doi: 10.2165/00019053-200119020-00007

${ }^{27}$ Clabaugh G, Ward MM. Cost-of-illness studies in the United States: a systematic review of methodologies used for direct cost. Value in Health. 2008;11:13-21. doi: 10.1111/j.1524-4733.2007.00210.x

28 Janssen I. Health care costs of physical inactivity in Canadian adults. Appl Physiol Nutr Metab. 2012;37;4;803-806. doi: 10.1139/h2012-061 
${ }^{29}$ Allender S, Foster C, Scarborough, et al. The burden of physical activity-related ill health in the UK. J Epidemiol Commun Health., 2007;61:344-8. doi: 10.1136/jech.2006.050807

30 Helmrich SP, Ragland DR, Leung RW, et al. Physical activity and reduced occurrence of non-insulin-dependent diabetes mellitus. N Engl J Med. 1991;325:147-52. doi: 10.1056/NEJM199107183250302

${ }^{31}$ Newschaffer CJ, Brownson CA, Dusenbury LJ. Cardiovascular disease. In: Brownson, CA, Remington PL, Davis JR. (szerk.) Chronic Disease Epidemiology and Control, 2nd Ed., American Public Health Association, Washington, DC,. 1998, pp 297-334.

32 Powell KE, Thompson PD, Caspersen CJ, et al. Physical activity and the incidence of coronary heart disease. Annu Rev Public Health. 1987;8:253-87. doi: 10.1146/annurev.pu.08.050187.001345

${ }_{33}$ U.S. Department Of Health And Human Services: Physical Activity and Health: A Report of the Surgeon General. Centers for Disease Control and Prevention, Atlanta, GA, 1996.

${ }^{34}$ Kokkinos P. Physical Activity, Health Benefits, and Mortality Risk. ISRN Cardiology. 2012;2012:14. doi: $10.5402 / 2012 / 718789$

${ }^{35}$ Franco $\mathrm{OH}$, de Laet $\mathrm{C}$, Peeters A, et al. Effects of physical activity on life expectancy with cardiovascular disease. Arch Intern Med. 2005;165(20):2355-2360. doi: 10.1001/archinte.165.20.2355

${ }^{36}$ Manson JE, Hu FB, Rich-Edwards JW, et al. A prospective study of walking as compared with vigorous exercise in the prevention of coronary heart disease in women. N Engl J Med. 1999;341:650-8. doi: 10.1056/NEJM199908263410904 ${ }^{37}$ Chomistek AK, Manson JE, Stefanick ML, et al. Relationship of sedentary behavior and physical activity to incident cardiovascular disease: results from the Women's Health Initiative. J Am Coll Cardiol. 2013;61:2346-54. doi: 10.1016/j.jacc.2013.03.031

${ }^{38}$ Gregg EW, Cauley JA, Stone K, et al. Study of Osteoporotic Fractures Research Group: Relationship of changes in physical activity and mortality among older women. JAMA. 2003;289:2379-2386. doi: 10.1001/jama.289.18.2379

${ }^{39}$ Powell KE. Population Attributable Risk of Physical Inactivity. In: Leon, A. S. (szerk.): Physical activity and cardiovascular health. Human Kinetics. 1997, pp 41.

40 Macera CA, Powell KE. Population attributable risk: implications of physical activity dose. Med Sci Sports Exerc. 2001;33:S635-9. https://www.ncbi.nlm.nih.gov/pubmed/11427788 (Elérve: 2017. 10. 10.)

${ }^{41}$ V. Hajdú P, Ádány R. Kockázati mutatók számítása. In: Ádány R. (szerk.) Megelőző orvostan és népegészségtan. Medicina Könyvkiadó Zrt., Budapest 2012, pp 42-48.

42 Katzmarzyk PT, Gledhill N, Shephard RJ. The economic burden of physical inactivity in Canada. CMAJ. 2000;163:1435-40. http://www.cmaj.ca/content/163/11/1435.long (Elérve: 2018. 01. 18.)

${ }^{43}$ Berlin JA, Colditz GA. A meta-analysis of physical activity in the prevention of coronary heart disease. Am J Epidemiol. 1990;132:612-28. https://www.ncbi.nIm.nih.gov/pubmed/2144946 (Elérve: 2017. 12. 04.)

${ }^{44}$ Paffenbarger RS, Hyde RT, Wing AL, et al. The association of changes in physical-activity level and other lifestyle characteristics with mortality among men. N Engl J Med. 1993;328:538-45. doi: 10.1056/NEJM199302253280804

${ }^{45}$ Arem H, Moore SC, Patel A, et al. Leisure Time Physical Activity and Mortality. A Detailed Pooled Analysis of the Dose-Response Relationship. JAMA Intern Med. 2015;175(6):959-967. doi: 10.1001/jamainternmed.2015.0533

${ }^{46}$ Guthold R, Stevens GA, Riley LM, Bull FC. Worldwide trends in insufficient physical activity from 2001 to 2016 : a pooled analysis of 358 population-based surveys with 1.9 million participants. The Lancet Global Health. 2018 Sep 4. doi: 10.1016/S2214-109X(18)30357-7

${ }^{47}$ Paffenbarger RS, Wing AL, Hyde RT. Physical activity as an index of heart attack risk in college alumni. Am J Epidemiol. 1978;108: (3)161-175. https://www.ncbi.nlm.nih.gov/pubmed/707484 (Elérve: 2017. 11. 04.)

${ }^{48}$ Balatoni I, Kith N, Csernoch L. Időskori sportolási szokások vizsgálata Észak-kelet Magyarországon. Magyar Sporttudományi Szemle. 2016;17:4-8. http://epa.oszk.hu/03400/03475/00065/pdf/EPA03475 MSSZ 201604 04-08.pdf (Elérve: 2017. 11. 16.)

${ }^{49}$ Herpainé Lakó J. The Issues of The Relationship of Grandparents and Grandchildren in the Light of Physical Activity. European Journal of Mental Health. 2014;9:178-94. https://www.ceeol.com/search/article-detail?id=95547 (Elérve: 2017. 11. 05.)

${ }^{50}$ Czabai V, Bíró M, Hajdu Pál. Az Eszterházy Károly Főiskola hallgatóinak életmódja, sportolási szokásai. Acta Academiae Paedagogicae Agriensis Nova Series: Sectio Sport. 2007;34:29-38. http://publikacio.uni-eszterhazy.hu/693/1/2938 Czabai.pdf (Elérve: 2017. 11. 05.)

${ }^{51}$ Borbély A, Müller A. A testi-lelki harmónia összefüggései és módszertana. In: Koncz I. (szerk.): Valóság-Térkép-6. PEM tanulmányok. Professzorok az Európai Magyarországért Egyesület, Budapest. 2008, pp 211.

52 Ráthonyi-Odor K, Ráthonyi G, Borbély A. Sportolni jó - felelősen a sport népszerűsítéséért. Agrártudományi Közlemények/Acta Agraria Debreceniensis. 2016;67:71-76. 
53 Pfau C. Examination of leisure sports alternatives provided by higher education institution. APSTRACT. 2015;9: 33-9. doi: 10.19041/APSTRACT/2015/3/5

54 Bendíková E, Dobay B. Physical and sport education as a tool for development of a positive attitude toward health and physical activity in adulthood. EJCE. 2017;6:14-21. https://eric.ed.gov/?id=EJ1137901 (Elérve: 2018. 02. 18.)

55 Dobay B, Bendíková E. Športové a rekreačné aktivity v životnom štýle dospelých. Exercitatio Corporis-Motus-Salus. 2014;6:19-31. https://www.ff.umb.sk/app/cmsSiteAttachment.php?ID=3419 (Elérve: 2018. 01. 21.)

${ }^{56}$ Dinyáné SM, Pusztai G. Use of the short (5-item) version of the WHO well-being questionnaire in first year students of Semmelweis University: Az Egészségügyi Világszervezet öttételes jól-lét kérdőívének vizsgálata a Semmelweis Egyetem elsőéves hallgatóinak körében. Orv. Hetil. 2016;157:1762-1768. doi: 10.1556/650.2016.30572

${ }^{57}$ Kovács K. Intézményi tényezők a debreceni egyetemisták sportolásában egy kvalitatív kutatás tükrében. In: Mrázik J. (szerk.): A tanulás új útjai. Budapest, HERA könyvek, 2016, pp 665-675.

58 Simon IÁ, Kajtár G. Az óvodás korú gyermekek rendszeres úszásának gazdasági értéke. Magyar Sporttudományi Szemle. 2014;15:57-58. http://epa.oszk.hu/03400/03475/00055/pdf/EPA03475 MSSZ 2014 02.pdf

(Elérve: 2018. 01. 08.)

59 Vitrai J, Bakacs M. Egészpályás letámadás a kövérség ellen - Komplex beavatkozásokkal az elhízás visszaszorítására. Egészségfejlesztés. 2017;58(4):40-49. doi: 10.24365/ef.v58i4.211 